Est.Ag 36 (2001) 31-61

\title{
Entre Sísifo y Dionisio. Evangelizar en una cultura trágica*
}

Una aguda observación de Ch. Dickens puede servir de punto de partida para establecer desde un principio el sentido de esta reflexión. Preguntaba el autor inglés: ¿qué es lo que fudamentalmente hay que conocer para enseñar latín a Charles? La respuesta espontánea del oyente parece obvia: se ha de conocer muy bien la lengua latina. Ante la aparente evidencia Dickens contrapone lo que pretende ser su mensaje: hay que conocer ante todo a Charles. Efectivamente sólo entonces se creará el ámbito de acogida y comprensión que hace posible la comunicación.

Esta actitud debe determinar la espiritualidad de todo evangelizador: en la actualidad resulta imprescindible conocer ante todo a nuestros contemporáneos, pues sólo entonces se puede comunicar de modo auténtico la originalidad de la buena noticia de Dios en Jesucristo. En estas páginas pretendemos exponer uno de los rasgos caracterizantes del hombre contemporáneo: se encuentra viviendo en una cultura trágica, y va en consecuencia asumiendo -de modo más o menos consciente-un modo de existencia trágica. Esta característica básica permite entender su sicología y sus formas de comportamiento. Este transfondo permitirá por ello comprender la novedad y la peculiaridad que puede aportar el mensaje cristiano precisamente en esta situación histórica, en la encrucijada actual de nuestra civilización y de nuestra Iglesia.

\section{1.- Una mirada a nuestra experiencia histórica y cultural}

Puede sorprender que demos tanta importancia al carácter trágico de nuestra cultura y de nuestros contemporáneos. Ciertamente es un aspecto que apenas es destacado en las descripciones y análisis de nuestra sensibili-

* Conferencia pronunciada en el Estudio Teológico Agustiniano, el 10 de octubre de 2000 con motivo de la inauguración del curso 2000-2001. 
dad histórica. Pero esto mismo resulta particularmente significativo dado que los mismos intérpretes y protagonistas de la filosofía española presente lo reconocen y lo proclaman abiertamente.

No es difícil sospechar las razones de este curioso olvido. La dinámica de nuestra civilización parece moverse en una dirección contraria a la tragedia: el objetivo de la emancipación y del progreso, el dominio de la razón y de la ciencia, el gozo de la vida y el disfrute de la abundancia de bienes de consumo proyectan un esplendor antitético de las sombrías escenas de la tragedia clásica. Sin embargo -y aquí radica el núcleo de nuestra tesis- eso es precisamente el componente trágico de nuestra civilización: la dinámica del progreso y de la ciencia, por sí misma, no conduce a ninguna parte, desvela por eso el absurdo de la existencia y las fronteras de la contingencia humana, por lo que no queda más salida o más posibilidad al hombre que el gozo -desenfrenado o controlado- de la vida, de las energías de la naturaleza.

Estas afirmaciones se pueden aplicar, como veremos más detenidamente, a la situación española. Pero apuntan más allá, mucho más allá. España no es una isla, sino expresión de la situación europea y del devenir de la modernidad. Por ello esta vía de análisis y de reflexión nos confronta con el destino de Europa y con las derivaciones de todo el proyecto cultural de los últimos siglos. Nos desvela dónde se encuentra la grandeza de la que se gloría el hombre occidental moderno (un saber que parece aumentar sin límites y una posibilidad siempre creciente de disfrute y de alegría) pero insinúa a la vez el vacío y el sinsentido de tales pretensiones. Es precisamente el carácter ilusorio de esas pretensiones el manantial de la corriente trágica que atraviesa y riega nuestra cultura y -en muchas ocasiones- también nuestros corazones.

Este nivel de la problemática nos permite poner de relieve una cuestión que nos interesa particularmente a nosotros: el papel del cristianismo y de la revelación bíblica en esa cultura trágica. Son cada vez más numerosas y significativas las voces que suscitan en toda su crudeza la cuestión de la presencia del relato cristiano en la actual encrucijada de la historia europea. No se trata ya de la secularización que se abre camino en virtud de la emancipación respecto al control o a las advertencias de la Iglesia. Se ha llegado a hablar de situación post-cristiana, en el sentido de que la conciencia europea moderna se ha situado en un estadio posterior al cristiano, si bien asuma -secularizados- algunos componentes del mensaje cristiano (como se puede constatar, por ejemplo, de modo claro en la celebración de la Navidad). Incluso algunos intérpretes han utilizado el concepto neopaganismo para designar la nueva experiencia histórica en la que las tradicionales referencias 
o símbolos cristianos se recubren de actitudes y de modos de comportamiento teñidos del paganismo antiguo.

A nuestro juicio sin embargo se debe hablar clara y directamente de paganismo para designar una sensibilidad que pugna por abrirse camino $\mathrm{y}$ que pretende ofrecer una alternativa a la "herencia judeo-cristiana" que, según algunos, ha destruído las potencialidades del alma europea al desgajarla de sus raíces pre-cristianas, paganas en sentido estricto. No todas las opiniones al respecto son tan radicales en sus juicios. La mayoría ni siquiera expresa con tal nitidez la apuesta que está en juego. Pero no hay duda de que nos encontramos en una situación en la que la mentalidad pagana intenta implantarse como vía de futuro práctico al considerar que no es plausible el cristianismo en el porvenir europeo que se está esbozando en el presente.

Como indicio de este nuevo horizonte baste mencionar la lógica que se esconde en algunas publicaciones recientes. Hypollite Simon, obispo de Clermont Ferrand, acaba de publicar La France devienne païenne?, cuyo provocador título muestra la evolución operada desde la reflexión planteada por Godin y Daniel hace seis décadas acerca de France pays de mission? Un libro-entrevista con Mons. Vlk, arzobispo de Praga y presidente de las Conferencias Episcopales de Europa lleva como título Wird Europa heidnisch? Un prestigioso intelectual alemán, Hans Meier, exministro de cultura y educación de Baviera y titular de la cátedra de Romano Guardini en la universidad de Munich, se ha planteado la inquietante pregunta sobre cómo podría ser una Europa en la que el cristianismo desapareciera (Welt ohne Christentum - Was wäre anders?) Desde otro punto de vista el filósofo francés A. Glucksmann ha escrito su último libro, La trosième mort de Dieu, para preguntarse porqué Dios ha desertado de Europa.

No necesitamos entrar en detalle en el contenido de estos libros y reflexiones para percibir con nitidez que nos encontramos, en Europa y en España, en una situación peculiar en la que el paganismo y el cristianismo, cada uno desde sus presupuestos y perspectivas, pretenden seducir el espíritu de los europeos. A nuestro juicio el punto de confrontación, la auténtica encrucijada, se produce acerca del carácter trágico de la existencia humana. El paganismo, resurgido después de siglos de marginación, se apoya sobre la tragedia. El cristianismo, en las actuales circunstancias, debe manifestar por ello la fuerza de seducción de una visión de la realidad que rasga las estrecheces de la experiencia trágica.

Inicialmente, y a modo de fórmula sintética, entendemos como trágica la existencia que, viviendo en los límites de la contingencia, se despliega sin un "appel", sin una interpelación de carácter personal que procede desde más allá de las "paredes del mundo". Reconducido a las fronteras de su propia 
contingencia, el hombre cuenta al menos con la energía de la vida misma, cuya plenitud se hace experimentable en el goce y en el júbilo de lo que se ofrece, que debe por ello ser aprovechado en toda su intensidad. Este doble aspecto, las limitaciones de lo finito y el júbilo de la energía vital que nos sostiene, constituyen el anverso y el reverso de esa sensibilidad histórica que denominamos como trágica.

Nos detendremos más adelante en algunos autores españoles representativos de ese doble aspecto mencionado. Pero previamente vamos a mencionar dos claves de interpretación de la cultura europea y de la experiencia humana desde el planteamiento esbozado. Esa doble clave ha de ser designada con nombres procedentes de la mitología griega, tal como han sido recuperados y repensados, respectivamente, por Camus y Nietzsche: Sísifo y Dionisio. El primero designa el carácter absurdo de todo proyecto humano, lo que empuja a la aceptación espontánea e intensa de la vida. El segundo pone un mayor énfasis en el apasionamiento desbordante de la inserción en el ritmo vertigionoso de la vida. Uno y otro permiten comprender la lógica y la coherencia de numerosas manifestaciones de nuestra cultura. Por ello pueden contribuir a que el cristianismo reconozca alguna de sus carencias y limitaciones, pero sobre todo debe hacer despertar a los cristianos de su somnolencia para que aporten su mayor originalidad, a fin de que el círculo trágico no se vaya cerrando sobre la Europa secular y sobre los corazones de quienes la habitan.

\section{2.- El destino de Sísifo: una felicidad sin interpelación}

El mito de Sísifo (1943) es una de las obras más representativas de A. Camus un hombre que experimentó profundamente el sinsentido y el absurdo de la existencia humana, pero que precisamente por ello encuentra la motivación profunda para la rebelión del hombre. Sísifo es el héroe (trágico) condenado por los dioses a elevar permanentemente una piedra hasta la cima de la montaña; una vez alcanzada la meta, la piedra se deslizaba hasta el pie de la montaña, lo que obligaba a Sísifo a reiniciar continuamente una tarea que no conocía ni descanso ni una meta definitiva. El Sísifo así presentado representa el punto de llegada de la acción de Prometeo. Este había sido condenado por Zeus a permanecer atado al Cáucaso como castigo por haber robado a los dioses el fuego, en virtud del cual pudo la humanidad emprender su larga marcha de desarrollo y de progreso, emancipándose de este modo de la vigilancia y del control de la divinidad. Prometeo fue por ello considerado como el modelo y el prototipo del hombre moderno, comprometido en la larga pero fructífera marcha en el proceso de afirmación del 
hombre por sí mismo. Cuando Camus habla de Sísifo está pensando en ese Prometeo que realiza su esfuerzo de emancipación sin una meta clara en la que pueda encontrar su descanso. El hombre moderno, Sísifo-Prometeo, es el destinatario y a la vez el protagonista de la reflexión de Camus, que toma nota del absurdo de ese proyecto histórico, pero al mismo tiempo proclama como mensaje salvador que no debe conducir a la desesperación o a la tristeza.

El sentido radical de El mito de Sísifo se puede aprehender desde el contraste entre las frases que abren y cierran la exposición. La primera afirmación de la obra es tal vez la más conocida: "No hay más que un problema filosófico verdaderamente serio: el suicidio"; juzgar si la vida vale o no vale la pena que sea vivida, es responder a la cuestión fundamental de la filosofía. La respuesta a esta cuestión se encuentra en las palabras conclusivas de la obra, menos conocidas pero aún más reveladoras: "Hay que imaginarse a Sísifo feliz" De modo sintético la vinculación de ambas ideas dibuja la tesis de fondo de Camus: la vida evidentemente no tiene sentido, es absurda, pero el suicidio no es la solución, hay que asumir la vida y el destino; ahí se encuentra la felicidad. No hay otra felicidad. Y esa situación, la del Prometeo convertido en Sísifo, puede ser ocasión de felicidad.

Sísifo, proclama Camus, es un héroe absurdo y trágico, pero feliz. Su desprecio a los dioses, su odio a la muerte, su pasión por la vida, la búsqueda libre de la propia redención, le ha valido un suplicio indecible. Siente el absurdo de realizar rutinaria y repetidamente acciones sin conexión y sin sentido, que nunca alcanzarán la consumación. El absurdo se impone cuando el hombre se siente extraño en el mundo, cuando éste se resiste a las pretensiones del hombre, cuando se pierden las ilusiones, cuando todo se hunde, cuando el vacío se hace elocuente, cuando se quiebra la cadena de los gestos de cada día, cuando el corazón busca en vano la malla que lo envuelve.

Cuando un estado de ánimo se hace consciente es cuando se vive en la tragedia, cuando el absurdo es tomado como tal. El mundo se hace espeso, extraño, irreductible, la razón muestra su impotencia, el ámbito de lo irracional hace ver su inmensidad, el espíritu llega a sus límites, no hay capacidad de claridad racional que permita comprender o iluminar una sensación tan radical. Las ilusiones se pierden y desaparece la esperanza. El hombre ciertamente se siente atravesado por el grito del corazón, por una profunda nostalgia de claridad y de unidad. Pero ello hace aún más patente el divorcio entre el espíritu que desea y el mundo que decepciona, entre la nostalgia de unidad y la dispersión de la experiencia del mundo. No se puede negar ninguno de los dos polos, pero tampoco conciliarlos. Por eso se origina un con- 
flicto trágico, precisamente a partir de la conciencia del absurdo. Ser consciente de que no se va a lograr nada, de que hay que desprenderse de toda esperanza, es lo que hace de Sísifo un héroe trágico. El hombre que hace todos los días lo mismo no vive trágicamente hasta que no se haga consciente de lo absurdo de esa vida. Sísifo es el héroe que ha cruzado ese umbral.

Ahí radica sin embargo su posibilidad y su dignidad, el manantial de su felicidad. Sísifo vive de una fidelidad superior, capaz de seguir negando a los dioses y por ello de seguir alzando su piedra. Su dignidad es esa protesta y esa rebelión. Esa lucha frente a los dioses, y su mirada retadora hacia las cimas, basta para llenar plenamente el corazón del hombre. Su capacidad de rebelión es la recuperación de su libertad, de su pasión por la vida. Eso le aleja del suicidio porque le aporta la felicidad que necesita.

La dignidad y la felicidad exigen aceptar la situación de una tensión que es inconciliable. Pero asumiendo lúcidamente de qué parte se encuentra el hombre; no sabe si el mundo tiene sentido, acepta su ignorancia, y por eso no comprende la realidad más què en términos estrictamente humanos: sólo lo que toca y lo que palpa es lo que se puede comprender. La razón es limitada, pero por eso hay que acoger sus poderes relativos. El hombre del absurdo ha olvidado esperar. Y un hombre sin esperanza no pertenece ya al futuro. Pero el presente, aunque sea un infierno, es al fin y al cabo su reino.

Esta tensión, asumida con lucidez y como rebeldía, puede ser manantial de vida, de la única vida posible. Por ello el hombre trágico debe rechazar toda actitud "iluminada" (o "iluminista") que considera que es posible una explicación del mundo. Y debe oponerse igualmente a toda "metafísica de consuelo", propia de tantas filosofías existenciales, que optan por la evasión y el salto, aún irracional, con tal de llegar a una meta. En este contexto critica explícitamente a Jaspers, Kierkegaard, Chestov: parten del absurdo, del choque entre lo irracional del mundo y la nostalgia de unidad que no se resigna a carecer de una meta. Por eso, de modo repentino e injustificado, buscan una razón para esperar, y en un acto ciego de confianza sostienen que, más allá de toda explicación, no se encuentra la nada sino un ser transcendente.

La auténtica reacción/rebelión ha de ser el deseo desesperado de vivir como su lógica existencial hasta la muerte. Por ello la rebelión excluye el suicidio. Lo que podría presentarse como invitación a la muerte se transforma así en regla de vida. Si es la muerte lo que origina lo absurdo, debe ser la vía para acrecentar la vida, para sentir la vida en la mayor medida posible. $\mathrm{El}$ absurdo hace ver que todas las experiencias son indiferentes, y por ello empuja a multiplicar las experiencias, a elegir la forma de vida que aporte lo más posible de esta materia humana. El mundo absurdo renace en todo su 
esplendor y diversidad. Don Juan es el modelo del hombre absurdo y de su pasión por la vida. Si va de mujer en mujer es porque las ama con igual comportamiento y en cada ocasión con todo su ser. Por eso se siente impulsado a repetir su don. Vive conforme a un claro principio: cuanto más se ama, más se consolida el absurdo, y cuanto más se siente el absurdo se produce un mayor empuje a amar.

El tiempo, la tierra, el cuerpo, lo finito, es el campo de la libertad humana, el único modo de experimentar y realizar la libertad. El hombre absurdo nada tiene por eterno y nada hace por lo eterno. Por ser perecedero puede realizar la aventura de su vida, pues ha identificado el campo de su acción. Es inocente, y queda sustraído a todo juicio que no sea el suyo. Una vida más grande no puede ser otra vida. Tal esperanza en otra vida sería un acto deshonesto respecto a lo que ha sido dado. Las alegrías más puras son las que se sienten sobre esta tierra. Esta vida que tenemos y experimentamos colma al hombre. La carne, aunque humillada, es la única certeza. No se puede vivir más que de ella. No hay más patria que la criatura.

Al no haber ni futuro ni mañana ni consuelo ni victoria ni eternidad ni inmortalidad, hay libertad. Y no como resignación, sino como testimonio obstinado de conformarse con lo que se sabe y se tiene. La révolte de esta libertad es lo que da su precio a la vida.

Este testimonio ha de ser contra el mundo irrisorio de los dioses. No hace falta appel. La única moral y la única responsabilidad es la que el hombre absurdo se dicta. Es incomprensible e inaceptable una libertad regalada por otro ser. El hombre es su propio fin. Su único fin. Liberado de la ilusión de otro mundo, sabe que no puede haber victoria. Por eso adquiere tanto valor la lucha en esta vida. También al margen de las iglesias. Estas están contra el hombre absurdo, porque pretenden lo eterno. Pero la vida en la tierra basta y satisface. Las llamas de la tierra bien valen los perfumes celestes.

En definitiva, como resume lapidariamente Camus, es posible mostrar que se puede vivir sin appel, sin una llamada, interpelación o relación que desborde la experiencia de este mundo. Este es el compromiso del hombre absurdo que asume lúcidamente su tragedia. La ausencia de appel ofrece como escenario y contenido la vida. Por eso el Sísifo-Prometeo da la espalda a los dioses para consagrarse al cultivo del esplendor de la vida.

\section{3.- Dionisio o el júbilo desbordante de la vida}

La figura de Dionisio pone de manifiesto la recuperación y el reencuentro de la alegría de vivir dentro de la experiencia de pérdida de la transcen- 
dencia. En este sentido se empareja con la figura y el símbolo de Sísifo. En ambos la tragedia deposita un deseo apasionado de vivir, que diluye las fronteras entre esperanza y desesperación. Uno y otro coinciden en la reivindicación de la inocencia del hombre, en el alejamiento del mundo de los dioses y de la eternidad, en la renuncia a buscar un sentido profundo de las cosas. La figura de Dionisio aporta sin embargo un aspecto peculiar respecto a Sísifo: mientras éste vive de la conciencia del absurdo y de la afirmación de la propia libertad (desde este punto de vista es aún "moderno"), aquél se sumerge de modo pleno en el fluir de la vida en todas sus contradicciones pero también en toda su voluptuosidad, que puede llevar (y que de hecho debe llevar) a la pérdida de la conciencia de sí. El portavoz y el profeta de esta nueva visión de la realidad es $F$. Nietzsche.

Nietzsche constituye sin duda uno de los pilares y de las coordenadas básicas de la civilización actual. No sólo debe ser considerado como uno de los "maestros de la sospecha" sino que, precisamente por ello, se ha convertido en uno de los "padres de la postmodernidad". Su método arqueológico o filológico se vuelve directamente contra el pasado cristiano de la tradición europea, pero igualmente contra las pretensiones de la modernidad. Por ello ha contribuído de modo decisivo a la eliminación de todo fundamento y de todo punto de referencia. En este proyecto la figura de Dionisio ocupa un papel y una referencia insustituible. Ya se encuentra presente desde los inicios de su producción literaria, cuando intentaba explicar El nacimiento de la tragedia (1871), y se prolonga hasta el final, en el grito que cierra su original autobiografía Ecce homo y que resume el punto de llegada de toda la reflexión de Nietzsche: Dionisio contra el Crucificado.

En esta misma obra comprende toda su producción literaria como una "misión", una "misión dionisíaca" que vive de la "sabiduría trágica". La misión de Nietzsche prolonga lo que fue la misión misma de Dionisio, que queda magníficamente condensada en la misión misma (del antievangelio) de Zaratustra. Sólo un dios, un Dionisio, puede experimentar el sufrimiento y la alegría de la vida como Zaratustra. Es la única vía de redención para el hombre.

Esta misión dionisíaca la vive Nietzsche apasionadamente, como un profeta, como el heraldo de un futuro inevitable. En cuanto discípulo del filósofo Dionisio, es consciente de que debe presentarse ante la humanidad para exigirle lo más duro que se puede exigir. Por eso sabe que su nombre irá unido al recuerdo de una crisis como jamás ha habido en la historia humana: la inversión de todos los valores. Pero precisamente por eso, por la radicalidad de su misión, reconoce que ha venido demasiado pronto, que no puede ser aún entendido, que él tan sólo anticipa lo que va a suceder dentro de dos 
siglos. Desde su soledad, se levanta sin embargo como el vigía de la llegada inminente e irreversible del dios del futuro, de Dionisio.

En esta reivindicación de Dionisio no puede ser considerado Nietzsche como original o pionero. Sin duda, como veremos, aporta novedades y radicalidad. Pero se inserta en una tradición anterior, que ya venía proclamando a Dionisio como el dios del futuro, como el Dios que ha de venir, como el dios del adviento. Ya los románticos desde sus orígenes habían denunciado la racionalidad de la Ilustración como algo abstracto y puramente analítico, porque disuelve y disgrega la realidad, considerada como un conjunto de elementos extrínsecos entre sí, carente por tanto de unidad vital. Por ello reclama un modo diverso de aproximarse a la realidad. Se impone como alternativa la necesidad de una nueva mitología, que no debe alimentarse de las tradiciones religiosas heredadas, sino de la reviviscencia de una experiencia de la realidad que sintetiza en un todo orgánico todas las dimensiones de la existencia humana, por tanto el sentimiento, la imaginación, la afectividad, la intuición estética, la sintonía con la naturaleza y sus energías vitales... Los poetas y los filósofos adquieren una conciencia casi sacerdotal, porque tratan de mediar una vía de salvación que libere al hombre de las escisiones y frialdades generadas por el uso seco y aséptico de la razón y de la ciencia. El antiguo dios Dionisio se convierte en el objeto de las esperanzas en esta nueva mitología.

¿Por qué se atribuye precisamente a Dionisio tal capacidad y tales potencialidades? Dionisio responde a las fantasías míticas de los románticos porque, como dios de la borrachera y de la poesía, es el único capaz de sobrevivir a la Ilustración. Ya entre los griegos parecía condensar en sí la esencia de todos los otros dioses, unificando en sí, y a la vez superando, todas las divinidades del Olimpo. Por eso Hölderlin lo considera el dios "que permanece" como "el siempre alegre y feliz". Se presenta por ello como el único capaz de rescatar al hombre de las sequedades y frialdades de la razón ilustrada.

Pero a la vez (en Hölderlin, Schelling y posteriormente en F. Nietzsche, Burckhardt y Rilke) es designado con el apelativo "el que vendrá", el dios del futuro, porque su señorío no se impondrá más que en el porvenir. Ya en su patria griega no fue reconocido en un principio. Era el dios de la promesa, desterrado en el extranjero, pero que retornará para sentarse finalmente a la derecha del padre o para asumir el señorío del mundo cuando los dioses olímpicos se hayan hundido en un general "crepúsculo de los dioses" (como valoraba Hölderlin la historia de la ilustración europea). Sólo Dionisio podrá mantenerse más allá de esta catástrofe del oscurecimiento de todo sentido. Será el protagonista de un pentecostés repetido en que los hombres 
reencontrarán la comunidad y la fraternidad en la alegría de la vida. Dionisio, el dios del vino y de la fiesta, de la exuberancia y del frenesí, deberá abrirse camino a pesar de tantas oposiciones. Pero la belleza de su culto se irá imponiendo por su evidencia, a pesar de los conflictos y de la violencia que desata, como muestra magistralmente Las Bacantes de Eurípides.

En El nacimiento de la tragedia Nietzsche asume a Dionisio y el elemento dionisíaco como clave para interpretar el origen y el sentido de la tragedia, y por ello las características propias del espíritu griego. No podemos en este punto desarrollar con detenimiento las tesis y argumentos de Nietzsche. Sin duda algunos de sus presupuestos o argumentos son discutibles y erróneos. Sin embargo permanecen en todo su valor aportaciones decisivas: a) hay que romper la visión "clasicista" del mundo griego, según la cual sólo lo apolíneo, lo racional, el orden y el equilibrio bastan para definir el espíritu helénico; b) no puede ser negado el contrapunto de lo dionisíaco, pues ello significaría negar y reprimir la fuerza y la energía de la naturaleza y de la vida; más aún, la tragedia no sólo se enraíza en los cultos dionisíacos, sino que se alimenta del antagonismo y de la búsqueda de reconciliación (imposible) de los principios apolíneo y dionisíaco; c) por ello, más allá de la cuestión de la cultura griega, obliga a plantear de otro modo el tema del destino de la naturaleza, del dinamismo de las fuerzas y energías naturales; la cultura y la civilización pretenden encauzarlas, orientarlas, organizarlas, equilibrarlas, pero no obstante siguen continuamente pugnando por hacerse presentes, por desplegarse; dicho de otro modo: los estilos de vida que la civilización establece se encuentran sobre unas fuerzas y energías que están continuamente amenazando todo presunto equilibrio y armonía.

Con esto queda establecido el nivel radical sobre el que se levanta la tragedia, que forma parte por ello del destino del individuo y de toda colectividad: no se puede dar una mediación o equilibrio que garantice la existencia en su ordenación aparente, el hombre no puede encontrar un oasis de paz o tranquilidad, sino que debe asumir la tensión de modo absoluto, sin la esperanza de una integración armónica de los extremos y polaridades.

La conexión genealógica de la tragedia con los cultos dionisíacos permite captar su sentido como parábola de la experiencia humana. La interpretación çásica de la tragedia ponía de relieve la idea de que la existencia humana no tenía sentido alguno sin la referencia a lo suprasensible (cualquiera que fuera la forma en que se comprendía esto). Por eso el dolor del hombre no puede ser afrontado más que desde una referencia superior a la propia vida humana. Nietzsche sigue un camino marcadamente distinto: el pesimismo de la tragedia es más bien un síntoma de fuerza y de poder, "del deseo... de la fuerza... de la salud que se desborda, de la plenitud inmensa". El pesi- 
mismo del sufrimiento no conduce por ello a la negación de la vida sino a su afirmación incondicional, como unidad e implicación inseparable de placer y dolor. El sufrimiento no se convierte en resentimiento contra la vida, sino que es afirmado precisamente a favor de la vida, como aguijón para el placer. El mundo de lo religioso queda de este modo reconducido -y reducidoa la vida. Existe una forma, tal vez se podría decir, de lo religioso a la que no corresponde contraponer la vida a lo suprasensible, sino fomentar la inmersión en la vida en toda su magnificencia, hecha de crueldad y de disfrute a la vez.

Esto significa una nueva valoración de la vida, de lo vital. Lo vital no tiene ningun sentido. Se realiza sin una teleología transcendente, según las leyes de la conservación, del desarrollo y del acrecentamiento biológicos. La vida no tiene ningun sentido o meta más allá de sí misma, de su conservación y potenciación. Cada vida es una lucha por más-vida, por una mejor apropiación de la vida, por un desbordamiento de las energías y del potencial de la vida, por el despliegue del deseo, del querer, del hacerse más fuerte, del querer crecer... La energía y la pujanza de la vida implican la violencia y la crueldad. Sin crueldad no hay fiesta. Porque la naturaleza es derrochadora sin medida, indiferente ante las crueldades inevitables, carece de intenciones y por ello de miramientos, de piedad y de justicia.

La tragedia consiste por tanto en la mutua implicación del elemento apolíneo y del dionisíaco en la existencia humana, en una tensión que nunca alcanzará reconciliación. La vida se expresa en diferenciaciones y en individualizaciones variadas que nunca logran la armonía. La individualidad, el hecho mismo de existir como conciencia y como individuo, es una parcialización de la vida, la más profunda herida en el mundo, que sólo puede curarse en la medida en que se produzca la reintegración en el fluir pleno de la vida (inconsciente) que todo lo envuelve y lo arrastra. El éxtasis, la embriaguez, el exceso, el frenesí, la voluptuosidad sin medida... son los reclamos que la vida ofrece a cada una de las conciencias enfermas por ser individuales. La tragedia no sólo lleva a la afirmación de la vida sino a la experiencia de la vida en su intensidad más frenética y desbordante. "Bajo el encanto de lo dionisíaco no sólo se restablece el vínculo entre hombre y hombre, también la naturaleza alienada, enemiga o sometida, celebra de nuevo su fiesta de reconciliación con su hijo pródigo, el hombre... Ahora, en el evangelio de la armonía de los mundos (Nietzsche está pensando en el canto a la alegría de la novena sinfonía de Beethoven) cada uno se siente no sólo unido, reconciliado y fundido con su prójimo, sino uno con todo, como si el velo de Maya se hubiera rasgado y flotara en jirones delante de la misteriosa unidad primigenia. Con cantos y danzas se expresa el hombre como miembro de una 
comunidad más elevada" (palabras que Nietzsche atribuye a la representación de una tragedia).

La tragedia afirma la vida sin resolver nada ni anular la problematicidad. Por ello requiere la dureza del martillo y el placer mismo de aniquilar. La vida debe ser asumida en sus tonos más extraños y duros. El devenir, la antítesis, la guerra, el fluir, las oposiciones socavan y destruyen lo estable, el equilibrio, el orden, los puntos de referencia, las normas, las tradiciones, lo fijo, el sentido, la verdad. Tener proyectos, objetivos, apostar por el progreso y las finalidades, pensar en clave de medios y fines... es signo de decadencia y empobrecimiento. Hay que sumergirse en el querer y el desear, hay que huir de sí mismo para alcanzarse a sí mismo en el más amplio círculo de la vida, en el manantial de la auténtica alegría. Sin principio ni fin, sin protología ni escatología, sin teleología ni orden moral, quedan abiertas todas las posibilidades, un movimiento incesante de múltiples direcciones, sin orientación y sin meta.

Por estos desacostumbrados caminos va haciendo su irrupción el nihilismo, "el más inquietante de todos los huéspedes". Al no haber centro ni meta ni fundamento queda el espacio de la inocencia y de la pureza. No hay sustancia oculta a la que agarrarse ni instancia que pueda exigir responsabilidades. Esa nada sin embargo no es el vacío sino el devenir de múltiples formas y el ritmo de la vida en sus múltiples variaciones. El nihilismo es el futuro y Nietzsche es su profeta.

Desde estos presupuestos adquiere toda su peculiaridad, su novedad y su fuerza el ateísmo de Nietzsche. No se trata evidentemente de una vulgar negación de la existencia de Dios. Es la proclamación de que se ha rasgado toda unidad, todo valor, toda esencia, toda verdad, toda divinidad, todo estado, toda ciencia. La muerte de Dios denuncia el fin no sólo del cristianismo, sino también del platonismo y de todas las pretensiones de la modernidad y de las ilusiones del hombre ilustrado, porque son formas diversas de la negación de la vida, sea que apelen a un Dios transcendente, a ideas suprasensibles o a objetivos a largo plazo.

El "hombre loco" de La ciencia alegre que proclama la muerte de Dios es consciente de la inmensidad del asesinato de Dios, realizado por los hombres, y de la enormidad de sus consecuencias. Por eso él mismo reconoce que la humanidad tiene dificultades para insertarse en la acción que ha realizado: "He venido demasiado pronto. No es aún mi tiempo. Este enorme acontecimiento está aún en camino. No ha llegado aún hasta los oídos de los hombres". El hecho sin embargo de que Dios ha muerto, de que la fe en el Dios cristiano se ha hecho inaceptable, "comienza ya a lanzar sus primeras sombras sobre Europa... Instalados entre el hoy el mañana... primogénitos e 
hijos prematuros del siglo inminente... deberemos tomar nota de las sombras que pronto invadirán Europa... Nos sentimos como iluminados por los rayos de una nueva aurora. Nuestro corazón desborda de reconocimiento, de maravilla, de presentimiento, de expectativa, por fin el horizonte empienza a aparecérsenos libre". Nietzsche advierte en Ecce homo, en síntesis, que está relatando la historia de los próximos dos siglos.

\section{4.- ¿Es trágica la cultura española actual?}

Sísifo y Dionisio nos desvelan una doble perspectiva de la misma lógica inmanente al desarrollo de la cultura moderna y contemporánea: la constatación de los márgenes delimitados para la existencia humana, que es a la vez encuentro con la vida concreta en sus posibilidades de disfrute y de placer, sea bajo la forma del apasionamiento donjuanesco (en Camus) o del desbordamiento voluptuoso dionisíaco (en Nietzsche). En el primer caso se acentúa la importancia de la razón, de la conciencia y de la autonomía (y en este sentido se mueve aún en el marco de la modernidad desengañada), mientras que en el segundo se pone más de relieve la inconsciencia y la inserción en lo otro de la razón (y en este sentido se despeja el camino para el despliegue de la sensibilidad posmoderna). Pero en uno y otro caso queda reivindicada la inocencia del hombre, más allá del bien y del mal, y un desplazamiento radical del sentido de la responsabilidad moral. Esta clave hermenéutica permite entender las raíces profundas, históricas y culturales, de los modos de vida de nuestros contemporáneos. ¿Qué nos dicen estas claves más concretamente de la sensibilidad cultural española de la actualidad? ¿Podemos decir que también domina el componente trágico, en su oscilación entre Sísifo y Dionisio?

A nuestro juicio también en España pugna por imponerse como evidencia esta cultura trágica, que se propone como alternativa al cristianismo y que por ello sirve como punto de apoyo y como cauce para la reaparición del paganismo, en algunos de sus múltiples rostros. En nuestra argumentación vamos a seguir un doble paso: en un primer momento vamos a presentar la conciencia trágica presente en la actual filosofía española, que ofrece los presupuestos para que -en un segundo momento- se despliegue una comprensión y una experiencia dionisíaca de la vida.

En el primer momento nos vamos a detener en tres filósofos, conocidos por el gran público y representativos de una sensibilidad general: Javier Sádaba, Eugenio Trías, Fernando Savater. En los tres se recurre al término tragedia (en Sádaba como "destino" o "fatalidad") para designar la realidad, la conciencia que se toma de ella, la filosofía que la expresa y el modo de 
existencia que la refleja. En los tres se asume un antagonismo, sin mediación y sin reconciliación, entre dos dimensiones o niveles que están separados por el límite que no puede ser rebasado. Porque se da ese límite es por lo que el hombre queda encerrado en sus márgenes, más allá de los cuales (o presionando sobre ellos) se impone una fuerza/energía/vitalidad que puede ser designado como lo sagrado, lo místico, lo hermético. Por la evidencia de ello es por lo que puede adquirir sentido y valor hablar de religión (siempre que no se entienda como religión positiva o revelada). Tragedia, límite, sagrado son por ello categorías clave de estos planteamientos filosóficos que pretenden aportar un mayor esplendor y unas mayores posibilidades a la existencia trágica del hombre, liberada de los ensueños platónicos, cristianos, marxistas, modernos o ilustrados.

Es común a los tres la referencia a Nietzsche. No asumen explícitamente su aliento dionisíaco. La razón y la individualidad aún defienden sus derechos. Pero comparten su proclamación de la muerte de Dios (en su sentido metafísico y cultural más amplio) y por ello el carácter no plausible (o superado) del cristianismo histórico o de la fe revelada. Siguen siendo por tanto testigos de una vida sin appel. Lo sagrado sigue siendo anónimo. Este establece una relación asimétrica con el hombre, pero carece de rostro y de nombre propio. Por eso entrega al hombre a una existencia trágica. Esta tragedia es vivida sin embargo con talantes diversos: como preocupación contenida en el caso de Sádaba, como aceptación constructiva en la filosofía de Trías, como explosión jubilosa en Savater. Veamos brevemente las analogías y las peculiaridades de los diversos autores.

El sentimiento trágico en Sádaba va unido al destino de la existencia humana: "lo que nos ha tocado está inamoviblemente ahí, no podemos variar lo que somos, no nos corresponde más que la aceptación consciente y compleja del destino". Ese destino consiste en la evidencia del límite. El ser humano es un ser no simplemente limitado, sino un ser de límites ("los límites nos son consustanciales"). El límite es un corte, una violenica, una brutalidad, un ruptura en la vida. El hombre por ello se siente incompleto, insatisfecho, desamparado, rodeado por un oceano de ignorancia. El hombre, inevitable y fatalmente, está él instalado en su finitud. Por eso sus anhelos e ilusiones carecen de esperanza y está condenado a moverse de modo tambaleante en un suelo escurridizo sin asideros. Han caído los ídolos. También las pretensiones del hombre. Los hombres se habían tomado por dioses y han descubierto que no son más que unos pobres diablos. Saben que tienen que ser felices pero no saben cómo. Por ello en la sociedad se ha instalado un inmenso aburrimiento que no sabe distinguir entre las expectativas y la desesperación. 
¿Dónde se encuentran las raíces de tal limitación, del carácter inevitable de los límites? Existen razones de carácter epistemológico: el método científico prohíbe rebasar las posibilidades de la experiencia, y por ello la fe carece de fuerza cognoscitiva. Existen igualmente razones de carácter ontológico: los valores se han desmoronado, no poseen densidad ni consistencia, carecen de una causa primera o última, se han perdido los fundamentos, que no eran más que un engaño. Y existen igualmente razones de carácter personal: su experiencia eclesial resultó frustrante ("pasamos por la Iglesia sin que ella pasara por nosotros", no aportó más que "aburrimiento, miedo, horror y sentimiento de culpa", por lo que "desde los años setenta pertenezco a otro" mundo). En este contexto, frente a la experiencia cristiana, resuena la alusión a Nietzsche y al gozo de la vida: hay que asumir "la rebelión para recuperar un gozo sustituído, unos placeres que han sido reemplazados por un Dios empobrecido, seco, montón de generalidades. Parece tener razón Nietzsche cuando afirmaba que su grito de que Dios ha muerto sería entendido un siglo después. Este siglo es el nuestro".

La sensación de límite sin embargo es la que hace posible la aceptación de la religión El hombre no puede sentirse cómodamente instalado en la finitud. El límite nos habla de las "paredes del mundo". Pero esas "paredes" nos encierran desde "algo" que presiona, nos envuelve y nos desborda. No podemos convertirlo en conocimiento. Pero tampoco podemos negar lo ininteligible que nos rodea. Es lo que (a falta de otro término más adecuado) denominaremos misterio (o "lo místico"). Y ello es lo que legitima la religión, en su sentido noble, al margen de toda positividad o de toda teología que no sea más que negativa. Resulta imposible responder a esas preguntas últimas y radicales. Pero tampoco podemos prescindir de ellas. Ahí radica la tragedia del hombre: en la falta de mediación o reconciliación entre ambos polos de la existencia humana. Pero ello es precisamente lo que hace posible una forma de vida religiosa alejada de toda creencia.

Eugenio Trías ha convertido la tragedia en un tema clave de su esfuerzo filosófico. Ya en 1973 escribió Drama e identidad para definir el carácter trágico de nuestra época histórica porque el hombre ha perdido el hogar y la posibilidad de retornar a él, ha perdido el lugar de refrigerio, y hasta las huellas que señalen el sendero hacia su hogar. No le queda más que la añoranza y el extravío. Su viaje es una migración por una tierra incógnita, sin meta ni orientación. Es un caos sin estrella, en el que no se puede esperar ni desenlace ni conclusión. El protagonista no es más que una subjetividad evanescente, sin identidad y sin nombre. El ejemplo paradigmático es el don Juan mozartiano: se compromete con las apariencias (vino, fiesta, canciones) a sabiendas de que detrás sólo está la Nada. Sabe que ha perdido su identidad. 
No lleva más que máscaras. Esas máscaras simplemente disimulan la Nada. Los personajes de S. Beckett encarnan magníficamente esa sensación: Godot es el espacio de la divinidad ausente, el espacio que se desmorona. Todo ello es el triunfo de Nietzsche: los valores venerados se han hundido, el centro está en todas partes, el océano del Acaso nos envuelve, la dispersión de colores fugaces nos entretiene. Tan sólo el vivir permanece como prueba contra el tedio, contra la asfixia del pensamiento.

Trías asume el límite (y lo sagrado) como centro de su reflexión filosófica, como estímulo para ir configurando un sistema con pretensiones de totalidad. El límite es la experiencia radical del hombre y su lugar de existencia, lo que le constituye como ser fronterizo. El límite articula y escinde un doble cerco, el del aparecer y el de "algo indecible" que presiona y que subsiste en un allende que no puede ser conocido; pero esto es lo que puede ser reconocido como sagrado o místico, si bien queda encerrado en su propio ámbito. El límite es línea y gozne, separa y (a la vez en cierta medida) une, pero salvaguardando siempre la inaccesibilidad de un secreto que es "lo encerrado en sí". Los límites epistemológicos señalados en Sádaba siguen actuando aquí con la misma fuerza y contundencia.

Este dato básico es sin embargo el punto de partida y el estímulo para La aventura filosófica: como fenomenología del límite ha de ir tomando conciencia de la paradoja radical de ese gozne y de lo que desde ahí se ofrece al pensamiento. Esa aventura filosófica es ciertamente una experiencia trágica, pues sabe que "lo místico" se recluye en el silencio, como cerco hermético porque le está cercando simultáneamente con su poderosa e invasora presencia/ausencia. El sujeto de la filosofía se sabe escindido: se reconoce como perteneciente al cerco del aparecer, pero remitido por una línea de fuga a ese allende que se mantiene en el silencio de su ausencia. Esta escisión se hace patente por ejemplo en el caso de la ética: el hombre escucha la "voz" procedente del allende que le ordena obrar el bien pero ni sabe exactamente en cada caso qué es lo bueno ni sabe el modo exacto de llevarlo a efecto. Se manifiesta igualmente en el campo de la estética, pues se siente empujado a la tarea imposible de encarnar en lo fáctico la belleza máxima.

Esta interna escisión, y la conciencia de que nunca logrará la reconciliación y la integración, constituye la condición trágica del hombre. Toda filosofía es asimismo trágica porque pretende ser absoluta sabiendo sin embargo que es justamente lo absoluto lo que hace imposible esa pretensión. Trágico en definitiva es el esfuerzo por neutralizar la condición trágica del hombre. Tampoco en Trías es posible una relación personal entre los dos cercos del límite, nadie con rostro interpela, espera, acompaña o acoge al hombre. Es significativo el hecho de que para designar lo que se esconde en la "nada" de 
lo "hermético" recurre con profusión a terminología o símbolos procedentes de la mitología no cristiana (Zeus, las diosas, las Madres).

De cara a nuestro tema nos interesa destacar la aplicación que, desde estos presupuestos, hace el autor a la historia y al destino de Occidente: siguiendo a Hölderlin, distingue entre el destino asiático y griego de un lado y el destino hespérico o moderno de otro, ambos diferentes y antitéticos. El primero, de carácter dionisíaco, facilita la manifestación de lo encerrado en sí, en toda espontaneidad y naturalidad mediante el fuego del cielo y los signos de lo sagrado; por el contrario el destino hespérico o moderno acentúa el factor cultura, que conduce a Grecia a separarse del origen, de lo dionisíaco, a una claridad que anula los "signos de lo sagrado"; su tierra es ámbito de aislamiento, noche despoblada de dioses. Pero precisamente por eso "los hespéricos están abocados a viajar hacia el Oriente y el Mediodía y a rememorar lo asiático y griego en busca de lo que les falta". Lo reprimido, por tanto, como nada o como dionisíaco, reclama sus derechos y sigue a pesar de todo ejerciendo su fascinación y su atracción a los hombres modernos en su propia tragicidad.

Fernando Savater vive la tragedia de un modo gozoso y jubiloso. La tragedia forma parte de su concepción del mundo y por tanto de su quehacer filosófico: "La ética trágica ha sido mi tema desde que... comencé a escribir filosofía". El sentido de la tragicidad inherente a la vida humana no puede entenderse al margen de la fuerza y del sentido de lo sagrado. La fuerza y el poder de lo sagrado es precisamente lo que hace que el hombre viva en una situación trágica, de la cual brota la energía y el esplendor de la vida.

Lo sagrado no debe ser comprendido desde las categorías religiosas inspiradas en el cristianismo o en cualquiera de las religiones reveladas o positivas. Savater se proclama "ateo militante", que lanza un anatema decidido contra toda pretensión sacerdotal y contra toda concepción personal de Dios, pero no tiene reparos en reconocerse como "ateo teligioso": "un ateo no tiene por qué carecer de sensibilidad religiosa ni de receptividad ante lo sagrado". Lo sagrado no dice referencia a lo transcendente sino más bien a lo inmanente, nada tiene que ver con Dios sino con lo más intrínsecamente humano. No se trata, por supuesto, de una fuerza inmanente que sea dominable y controlable por el hombre o que pueda ser objeto de reflexión cognoscitiva por parte de la razón humana. Lo sagrado designa un amplio consorcio de fuerzas y de sustancias, cuya abrumadora grandeza y radical extrañeza a la vez exaltan y aterran. Es "lo que por esencia nos ignora sin que nosotros podamos ignorarlo, lo que no nos concede importancia y por eso mismo tiene importancia para nosotros". Es una alteridad que se hace presente sin palabras y sin razón, como la azarosa plenitud de la inmanencia. 
Establece una asimetría en la que el hombre queda sometido y subyugado. No es el orden, la ley, la norma, la razón o lo personal lo que constituye ese fondo último del que todo emerge. Es más bien caos, voluntad, querer, deseo.

Sería por ello superstición concebirlo como un ser personal o suponer que puede aportar pautas claras para el comportamiento humano. Nietzsche tenía por tanto razón al proclamar que Dios había muerto. En su soledad, el hombre se descubre como un ser trágico, pero a la vez penetrado por el júbilo de todas las posibilidades. La tragedia se impone desde una doble perspectiva: a) a pesar de que existe el destino y la fatalidad (mejor dicho, precisamente por ello) es posible la acción, como voluntad de determinarse a querer por sí mismo; b) el yo brota como individualización que se contrapone al todo, y por ello la vida es dolor perpetuo (como había indicado Nietzsche); cada hombre es un dios (porque procede de lo sagrado) que nunca puede superar la humillación de haberse hecho hombre ( $\mathrm{y}$ por ello individuo, limitado).

Esta situación trágica es sin embargo el gozo del hombre. Está condenado a la irreconciliación, pero puede experimentar la pasión por ir abriendo posibilidades siempre nuevas. Al hombre nada le falta, si bien nunca tendrá bastante. Ni debe caer en un optimismo que considere que superará el conflicto que le constituye ni en el pesimismo de quien no ve más que la frustración de sus expectativas o proyectos. Nada va a arreglarse porque nada hay que arreglar. No hay otro mundo que este y este es así. Pero el hombre, en virtud de su querer y de su desear, puede ser fuente de valores que manifiesten el esplendor exuberante de la vida. En la vida, el hombre queda remitido a su querer y desear, y por ello sus acciones permiten experimentar todas las dimensiones de la vida, de eso sagrado que nos desborda pero que a la vez nos ofrece posibilidades múltiples, inacabables e insospechadas. La tragedia, en consecuencia, es la condición necesaria para experimentar la plenitud de la vida.

\section{5.- El protagonismo (dionisíaco) de la Vida}

Situado el hombre en el marco limitado de su experiencia, recupera ésta en la energía de una fuerza que la sostiene, la alimenta y le ofrece innumerables posibilidades por explorar. De este modo la experiencia -tan limitadaes reencontrada como Vida, lo único que, en su plenitud, merece la veneración que se atribuía a lo sagrado en las religiones tradicionales. Son numerosos los testigos que en la cultura española avalan esta sensación y este desplazamiento. Menos directamente en el campo de la filosofía, pero 
abundantemente en el campo de la literatura. Como botón de muestra nos fijaremos en dos autores de éxito, que sin duda sintonizan con una sensibilidad muy extendida: Antonio Gala y Terenci Moix. En ambos se asume el carácter trágico de la existencia, que es integrada en una concepción de la vida impregnada de un paganismo que en ocasiones es reconocido y proclamado como tal y con unos tintes dionisíacos que no son ajenos a la impronta nietzscheana.

El caso de Antonio Gala puede ser representativo de los desplazamientos de sensibilidad que se han producido en una generación. Todavía en el temprano Los verdes campos del Edén (1963), que le abrió la gran puerta del éxito literario, abundan las resonancias de su procedencia cristiana, centrados en los símbolos de la redención y del amor; se trataba ciertamente de un planteamiento "humanizado", pero aún no desgajado de su matriz originaria. Posteriormente, en paralelo con el proceso de transición política, sus obras se centraron en temas como la igualdad, la justicia, la democracia (sintetizados magníficamente en la "trilogía de la libertad"), con un mayor acento crítico respecto a la sociedad burguesa, a la moral tradicional y a la religión heredada. A nuestro juicio, una vez experimentada la desilusión de los proyectos socio-políticos, eclosiona como tema y preocupación central aquello que puede sostener al hombre en su desilusión: la Vida. Como expresión clara de este último paso en el desarrollo del pensamiento de Gala podemos mencionar dos obras: el drama Carmen Carmen (1988) y la novela El manuscrito carmesí (1990).

Carmen, la protagonista, encarna de modo total la alegría de vivir. Esa alegría es todo, porque hemos nacido para la alegría. Ella es una heroína trágica porque, como indica el mismo autor, en ella se produce "la exposición de la más enconada tragedia de los seres humanos. Porque, nacidos para la felicidad, hemos transformado, a causa de nuestras menudas ambiciones, el mundo, previsto como un valle de gozo, en un valle de lágrimas. Nos mueve, más que el jubiloso cumplimiento de nosotros mismos, el ansia de dinero, de poder, de difusas espiritualidades, de una gloria aún más difusa, o de un incomprensible concepto del honor. Los hombres, desde hace siglos, vienen asesinando su propio destino de alegría. Si a la alegría de vivir se la personificara, cada uno tendríamos más de un cadáver dentro del armario. No otra es la razón de la angustia humana, que teme lo mismo que desea, y mata lo que añorará". Vemos, por tanto, una raíz de la tragedia humana: poner frenos a una felicidad que se le ofrece, impedir que el gozo de vivir sea aceptado en su pureza e inocencia (veremos después que la misma vida, aún aceptada, encierra en sí una dualidad que igualmente podría ser calificada como trágica). 
Fruto de esta tragedia de todos los hombres es la tragedia misma que ha de padecer Carmen: ella, seductora momentánea, acaba siendo una perdedora; sus cuatro amantes (el militar, el político, el religioso, el torero) serán seducidos momentáneamente, pero al final retornarán al orden constituído y asesinarán a ese espíritu utópico y libertario.

Carmen proclama con convicción su buena noticia: el hombre no nace empecatado, nace para ser feliz y experimentar la alegría de la vida. Dios mismo es profundamente alegre, y por ello no puede querer que sus hijos sean tristes. Dios ha bendecido los dinamismos de la vida y por ello pueden y deben ser disfrutados por los hombres. Hay que acallar la voz de quienes atribuyen a Dios determinados mandatos o prohibiciones que van contra la alegría, el goce y la vida. Desde estos presupuestos proclama Carmen su mensaje:
¡Alegría! ¡Alegría!
Hemos nacido para la alegría
Si a ser alegre aquí
Le llaman pecar
Vamos a cometer
Pecado mortal.
Si ser alegre aquí
Es una rebelión
Vamos todos a hacer
La revolución

¡Alegría! ¡Alegría!
¡Hemos nacido para la alegría!

Carmen reprocha a la sociedad los estrechamientos o sucedáneos de ese gozo de la vida: o prejuicios morales o normas religiosas o bienes de consumo. "¿Y sabes lo que hago yo con vuestra sociedad? Me la paso por debajo de la pata... Una gente que no quiere molestarse en vivir. Una gente que no sabe si enorgullecerse o avergonzarse del mundo en que vive. Coches, músicas celestiales, gramófonos, electricidad, fabada en lata, todo. Sí, señor: ¡todo! Qué aburrimiento. La única diversión que os queda es mataros unos a otros como quien tira al plato... ¿A esto lo llamais la sociedad del bienestar? Pues, hijo mío, os la podeis meter en donde os quepa". Frente a ello ofrece su alternativa: "Si quieres alegrarte / ven conmigo / ... Deja a los santos tristes / rezar a tristes santos / Tú agárrate a la vida / y vámonos".

Más amplia, pausada y profunda reflexión sobre la vida subyace y sostiene El manuscrito carmesí, que presenta bajo forma de memoria y rememoración el destino de Boabdil, el último rey de Granada, "la mejor personifica- 
ción de un pueblo condenado a abandonar el Paraíso". Pretende ser por tanto el portavoz y el paradigma de la condición humana, y refleja sin duda la postura personal del autor.

Boabdil pretende ser portavoz y defensor de la vida frente a dos posturas rechazables: las tendencias islámicas ortodoxas o fundamentalistas y el cristianismo. A uno y otro reprocha la tendencia a querer particularizar a Dios, suprimiendo la universalidad de un Dios común a todos los hombres que no necesita mediadores que manipulen o monopolicen su voluntad. De cara a nuestro tema interesa más poner de relieve desde los ojos y la sensibilidad de Boabdil las insuficiencias del cristianismo, que se condensan en definitiva en su reticencia a gozar y experimentar el esplendor de la vida, tal como se muestra en los castellanos de aquella época: refieren todo a una eternidad amenazadora que hace tristes sus vidas y sus muertes, sacrifican todo a un futuro del que no tienen testimonios ciertos, llevan vestidos pardos y rudos, rechazan los baños como pecaminosos, aspiran a una perennidad inconcreta frente a lo inmediato y al ahora, son ásperos y rudos porque no cultivan el refinamiento y las formas, no son capaces de recrearse en los juegos del agua, evitan los perfumes... "Todo es tosco y elemental entre ellos".

Dios no quiso un valle de lágrimas como hogar del hombre. El hombre sin embargo se encuentra en exilio, fuera del paraíso. La existencia terrena es fugaz y el hombre un ser efímero. El presente es nuestro único bien. Por ello en y desde el presente hay que reconciliarse con la vida. Pero no para enriquecerla (es la cuna de todos los bienes) sino para gozarla. Es la urgencia de gozar la que debe mover a los seres humanos. Pero ha de ser un goce concreto e inmediato: la experiencia del sexo, de la caricia... pues en caso contrario la Vida caería en lo inconcreto e indeterminado.

La vida está por encima de todo, porque lo envuelve todo y lo es todo. De hecho puede ser identificada con Dios o, dicho de otro modo, suplantarlo y sustituirlo. La vida es un Dios perpetuamente manifiesto y a la vez silencioso. No se extingue jamás, sino que se transforma, irisada y ubicua. Lo invade todo y todo es signo de la vida (incluso la muerte). La vida es lo que importa, no el individuo concreto o el yo particular, ni siquiera una vida concreta. Ella es la que se manifiesta y se esconde en la multiplicidad de manifestaciones. Se ofrece tan sólo para exigir que la vivamos, con ciega confianza y con gozo creciente. Para engendrar y alimentar la vida ni siquiera hay que amarla, basta entregarse a ella. Ella hace lo demás.

Este carácter total y pleno de la vida explica la ambivalencia que la caracteriza. Es providente y materna, es comprensiva y misericordiosa. Pero también es avasalladora, ecuestre, jocunda, y puede ser hasta implacable e inflexible. La vida nos crea y nos usa como instrumento, sosteniéndonos y a 
la vez dejándonos y abandonándonos. Nos deslumbra, seduce y atrae, pero luego continúa sin nosotros. La dualidad se impone como tal cuando no la desciframos o cuando pretendemos comprenderla o dominarla. Pero con ese tipo de verdad no se va a ninguna parte. Menos aún a la vida. La vida es un todo. Y esa vida es a la vez palpitante y sangrante. Es una enrevesada continuidad de rupturas, un rumor de manos agitadas que nos dicen adiós. Tira de nosotros en momentos de abatimiento. Pero si nosotros aparecemos en ella, lo hemos de hacer como individuos, y por ello el amor y el dolor van unidos en la existencia humana. Pero el goce y el placer pueden hacernos penetrar en su intimidad, en su unidad total, en su fluir y en su plenitud. "Poseído por esa embriaguez (se refiere al acto amoroso), en que se deja de vivir por vivir más, o en que uno deja de ser uno mismo para confundirse con todo lo que goza, con todo lo que vibra, con todo lo que palpita en este mundo, he pensado a ráfagas qué breve y sucedáneo es el deleite de la masturbación comparado con este otro, tan inducido como compartido, donde la crueldad y la generosidad, el egoísmo y la largueza se enredan y confunden".

Otro de los autores de éxito, exponente de la sensibilidad de una época, Terenci Moix, nos abre una perspectiva en la que lo dionisíaco se tiñe de tonos donjuanescos. Debelador por una parte de las máscaras carnavalescas de una sociedad que vive de apariencias, se declara él mismo prendido y envuelto en disfraces, imágenes y fotocopias de la realidad. ¿Qué es lo que hay debajo de las máscaras y de los disfraces? O bien la vida que resulta inalcanzable o bien la nada. En cualquier caso (aunque no sea un término que posea especial fuerza en el autor) la tragedia. Desde esta perspectiva se puede captar la clave hermenéutica que ofrecen las palabras con que cierra la autobiografía de sus primeros años en torno a aquella plaza que da título a la obra El Peso de la Paja. El cine de los sábados: "Todavía hay dos cosas que exigen un respeto. Los pavorosos abismos de un alma en soledad y la infinita misericordia de los sueños". Lo primero nos habla de la tragedia. Lo segundo de la actitud existencial que debe caracterizar esa existencia trágica.

El autor proclama como divisa de su vida haber nacido con el don divino de la risa y con la convicción de que el mundo estaba loco. Pero ello no puede ocultar ni disimular los rasgos que marcan trágicamente la existencia humana en general y su personal biografía: en un nivel de la experiencia constata la profunda y radical soledad que le envuelve, situación irremediable, que va acompañada de una desesperada melancolía ("me siento solo porque soy humano"); a un nivel más profundo, se comprende que la vida es un exilio permanente, que la herida del tiempo hace sentir como lamento todo lo irrecuperable de la existencia; la fugacidad del tiempo y el drama de crecer sitúan al hombre en su verdadera condición; desde otra perspectiva se 
pueden identificar tres focos de la tensión insuperable que constituye al hombre como ser carente de reconciliación: la pugna entre los deseos y el curso indominable de los acontecimientos (el ideal nunca se puede encarnar en la realidad, el hombre queda siempre de un lado y el mundo de otro, sin que sea posible establecer puentes entre las dos orillas); la confluencia en el hombre de partes múltiples que no se resuelven a ser nada, la referencia constante a la vida sin conseguir dominarla, comprenderla o interpretarla.

¿Cómo afrontar la situación existencial? ¿Se ha de optar por la risa o por la seriedad? La seriedad no conduce a ninguna parte ni tiene justificación. Pero tampoco la risa puede ser absolutizada. En consecuencia no queda más remedio que reconocer la fuerza de la Vida (así, con mayúscula), pero su fuerza se nos escapa, por lo que debemos relacionarnos con ella por medio de los juegos, los disfraces, las máscaras. Por un lado "la Vida me ha elegido, no yo a ella. Yo sólo soy un accidente". Pero por otro lado "imito continuamente la vida sin conseguir interpretarla". En esta oscilación se moverá la existencia humana, y por eso los sueños aportan una infinita misericordia para soportar los pavorosos abismos de un alma en soledad.

La época ofrece a cada instante un ritmo frenético, lleno del eclecticismo propio de la ausencia de referencias, pero por eso mismo abre posibilidades apasionantes para la vida. La sensibilidad del momento legitima el derecho a la transgresión, a realizar viajes fabulosos que no tienen fronteras, con vestidos siempre cambiantes. La aventura permanente es el aliciente de la vida. Por eso los disfraces pueden transcender la realidad. Los mitos pueden esquivar la dureza de la realidad. La multiplicidad de fotografías de una realidad evita la rutina y el aburrimiento en que acaba todo lo permanente. El cine sustituye todo intento de realidad por retazos de ficciones. El Egipto soñado abre perspectivas que desbloquean la opacidad de lo cotidiano. La obsesión por las máscaras y el juego entre las apariencias y la realidad tiene algo de inquietante (viven de la tragedia) pero representan a la vez el aliciente de la aventura de la Vida. Este modo de situarse ante la realidad sólo es posible desde una actitud moral que no sabe discernir las fronteras entre lo bueno y lo malo, entre lo natural y lo antinatural. La moral por tanto también se libera de las imposiciones de la realidad y de los criterios heredados. Ello sin embargo no anula la situación trágica, porque el juego de máscaras no permite ni solución ni reconciliación, porque hace imposible conocer la verdadera identidad de las personas.

¿Y qué sucede con la religión? Resulta inevitable que se rechacen igualmente las formas de la religión tradicional, que en sus años de infancia actuaron como imposición, intolerancia, como represión, como cárcel. Estos juicios forman parte de los tópicos de toda una generación. Desde nuestro 
planteamiento nos parece significativo destacar algunos aspectos especialmente relevantes. La imagen adoptada por la religión se oponía a los deseos y apetencias del hombre, a sus intereses, y por eso suscita sentimientos de remordimiento y de culpa. Los símbolos cristianos fundamentales se le aparecieron como la negación de la vida: la figura del crucificado, agonizante y exangüe, permaneció como una "imagen de horror"; los modelos del martirologio cristiano (como dejó expresado en El sadismo de nuestra infancia, título en sí significativo) reflejaban también el lado oscuro de la religión, el que tiene como base los sufrimientos, el sacrificio, el derramamiento de sangre en nombre de un ideal superior, en definitiva el anquilosamiento de la vida.

Aún más relevante de cara a la tesis que pretendemos expresar es el modo como T. Moix comprende la Semana Santa y la Pascua. La Semana Santa, saturada de rituales lúgubres, presentaba una religión que chocaba con los antojos del hombre. Los dones de la vida se retrasaban hasta la Pascua. "Fui niño de Pascua, niño de la alegría inconmensurable de la Pascua de resurrección, criatura ávida de todos sus obsequios". Desprovista de su carga religiosa, la resurrección de Cristo toleraba todas las intromisiones paganas, permitía el desbordamiento de la alegría, el júbilo de la Pascua se correspondía más fácilmente con los deseos humanos y con las tendencias del mundo. Se acercaba a la victoria y al triunfo de la primavera, y así era posible que se correspondieran "mis necesidades con las de la Naturaleza". La alegría de la carne, el supremo reclamo del paganismo, podía abrirse camino en vinculación con la Pascua. La religiosidad espontánea de lo natural recubre por tanto las estructuras religiosas tradicionales, dejando paso al paganismo que respeta y recoge la alegría de la carne, del mundo, de la Naturaleza, de la primavera, en definitiva de la Vida.

\section{6.- Lo dionisíaco(-donjuanesco) como experiencia de la vida}

La experiencia de lo trágico, tal como lo hemos presentado, y sus derivaciones dionisíaca y donjuanesca, se han ido configurando como infraestructura de un modo de situarse en la realidad. Sus manifestaciones son múltiples, y aparentemente heterogéneas, pero todas ellas se dejan comprender mejor como expresión de estos dinamismos internos a nuestra civilización.

Conviene, a esta altura de nuestra exposición, sintetizar los grandes ejes en torno a los que gira la mentalidad trágica: a) supone el descubrimiento, reconocimiento y aceptación de los propios límites; la contingencia es el destino del hombre, sin horizones de sentido transcendente y sin puntos de referencia vinculantes; por tanto no hay appel personal, el todo que envuelve al 
hombre es anónimo, y desbordante precisamente por su impersonalidad; b) el hombre se siente escindido por la individualidad que se contrapone a la totalidad envolvente, por la inadecuación entre sus deseos y una realidad que se resiste, por la pluralidad de tendencias que en él se desatan y las nostalgias que afloran permanentemente; ni la reconciliación ni la armonización equilibrada pueden ser objeto de esperanza; c) el hombre sin embargo está obligado a la acción, precisamente como reto al destino, porque están abiertas múltiples posibilidades; estas posibilidades quedan acentuadas precisamente porque no existe una clara distinción entre el bien y el mal o un punto de referencia que pueda unificar la pluralidad de sus actuaciones; d) la esperanza queda sustituída por la reacción y la rebelión: se asume el grado de autonomía de que se dispone, que se ejerce sobre la base del querer, como expresión de la energía vital de la que emerge el hombre; e) el comportamiento del hombre queda oscilando entre la convicción de que "no todo está permitido" (como exigencia de la razón y de la dignidad del hombre) y la necesidad de la transgresión (precisamente como lucha contra toda norma establecida, pero siempre con la imprecisión de delimitar cuál debe ser el freno o el límite de la necesidad transgresora).

En esta concepción de la tragedia, como se puede comprobar, se han integrado muchas de las convicciones fundamentales del mensaje nietzscheano: la muerte de Dios, el hundimiento de los valores y fundamentos, la ausencia de verdad estable, el desdibujamiento del centro y de la meta, la necesidad de encauzar el dinamismo de las fuerzas inconscientes... y por ello la opción de ser más bien sátiro que santo.

Esta opción se concreta en el talante dionisíaco: hay que rescatar al hombre de su sufrimiento y de los fardos (morales y religiosos); para lo cual (aunque no se pueda eliminar lo que implica de violencia y crueldad) hay que afirmar la vida, como manantial de alegría, con la inocencia del niño que ríe, canta, juega, danza; así se sumerge el hombre en el querer y el desear, al margen de lo que sea estable, fijo, norma, tradición, equilibrio; en ese permanente fluir y devenir, el hombre busca huir de la individualidad para reencontrarse -mediante la fusión con el todo provocada por el exceso- en el todo vital del que emerge el hombre. La actitud donjuanesca evita los tonos más crudos y violentos, pero representa un modo análogo de rebelión en/desde la vida, apoyado en un juego de máscaras que esconden igualmente un vacío de identidad, que se mueve oscilante sobre la multiplicidad de experiencias y aventuras.

Desde la perspectiva que ofrecen estos diversos elementos podemos comprender en toda su hondura y alcanzar una amplia gama de manifestaciones de nuestra sociedad. Pueden parecer elementos heteróclitos, como si 
fuera un cajón de sastre, pero reciben una luz clarificadora desde sus raíces y presupuestos.

Nuestra civilización vive en gran medida de la racionalidad (o, mejor, racionalización) heredada de la Ilustración y de la modernidad. La actual experiencia de globalización, con su base técnica y económica, con sus bienes de producción y de consumo, son su prolongación actual. Pero precisamente la fuerza y la presión de este marco de civilización deja el corazón frío, reprime otras apetencias o necesidades del hombre. Y no se ve alternativa para destruirla desde fuera y tampoco existen energías o confianza para transformarla desde dentro. Por ello se hace necesario el equilibrio que aporte otro modo de experiencia, que prescinda de la racionalidad de fines y medios y permita reencontrarse con aquello que se ofrece: la vida y el goce de la vida.

La búsqueda del consumo y del placer, como objetivo constante es el modo posible y actual de aferrarse a los dones de la vida. Especialmente cuando se convierte en obsesión por "vivir bien" y por disfrutar de la vida. La obsesión es la fuerza inconsciente de la huida, más allá de controles racionales. La fiesta y el fin de semana se convierten en una meta que se renueva cada día o cada semana. Tanto el trabajo como el estudio no son más que momentos de paso (túnel) hacia el momento de ocio (la claridad y el esplendor de la vida). El homo ludens es la figura renovada de Don Juan y de Dionisio. La organización y la racionalidad de las sociedades desarrolladas, que pueden recurrir a las máquinas o a los inmigrantes para otro tipo de trabajo más duro o más servil, permite que se manifieste con nitidez un lado oscuro de la experiencia, que en numerosas ocasiones no se quiere reconocer como tal. Los nuevos dioses o las nuevas máscaras se ofrecen a la humanidad contemporánea -y rica- como sus posibilidades de existencia al alcance de la mano. Y a través de ella se abre como horizonte para el conjunto de la humanidad.

La valoración del cuerpo y del sexo, la erotización de la sociedad, la potenciación de sensaciones múltiples, la creación de nuevas necesidades y deseos, la estimulación de apetencias... son manifestaciones visibles de la efervescencia de la vida, comprendida y utilizada demasiadas veces de un modo biológico craso, como despliegue de los componentes inconscientes e impersonales de la naturaleza. El flirteo y el juego de la seducción expresan magníficamente esta actitud: es una historia de amor que se concluye aún antes de haber comenzado, pues se alimenta del sueño y de la imaginación. Pretendiendo dominar el aburrimiento que acecha y socava toda relación o todo vínculo estable y permanente, crea posibilidades de vida sin consumación y sin compromiso. 
La alabanza de la transgresión es la justificación de posibilidades y aventuras que quedaban cortadas desde los criterios morales clásicos. El "pruébalo todo no vaya a ser que pierdas alguna experiencia" se ha convertido en divisa para un amplio sector de las recientes generaciones. La aventura, y las experiencias cambiantes, forma parte de la moral asumida. Ciertamente pueden existir criterios sociales que encauzan determinadas iniciativas, pero tales criterios están expuestos al fluir de los acontecimientos y al devenir de las apetencias. Ello no significa negar la existencia de otras opciones asumidas también por las nuevas generaciones (solidaridad, voluntariado etc.). Significa simplemente afirmar que la sensibilidad actual es polimorfa $y$ ambivalente. Y por ello no puede entenderse en su complejidad al margen de la base trágica que subyace a un modo contemporáneo de situarse en y ante la vida.

El mundo juvenil, en amplios estratos, refleja con claridad muchas derivaciones de la corriente cultural que estamos comentando. Tanto en el exceso de las sensaciones, como en la disolución del yo-conciencia, como en las explosiones de violencia y agresividad. Baste pensar en los excitantes que permanentemente se actualizan y renuevan, en el uso extendido de la droga, la implantación de la borrachera y del alcohol, la práctica del sexo libre, el modo de vivir los fines de semana (basado en estímulos que puedan mantener el grado mínimo de conciencia...). La multiplicación de sensaciones intensas se mueven en la frontera de la conciencia, en el vértigo apasionante de diluirse en un todo más grande en el que superar los dolorosos límites de la propia individualidad.

El mundo juvenil refleja de modo especial en algunas de sus manifestaciones las huellas de lo dionisíaco. La multiplicación de sensaciones apunta a una fusión en un todo más grande que funde todas las conciencias. Muchos espectáculos de carácter musical pretenden un éxtasis colectivo. El mundo de la noche y juego de las luces de colores, acompañado del ruido ensordecedor, permite crear un ámbito supraindividual en el que todos se sitúan más allá de las relaciones personales centradas en el encuentro y la comunicación yo-tú. Algo semejante podría decirse de la celebración de las Love Parade, tal como se realizan especialmente en Berlín (y sus imitaciones en Tel Aviv, Buenos Aires o Leeds). Las crónicas del evento recogen alusiones al exceso y a la desmesura de más de un millón de jóvenes, presentados como adoradores de ritmos electrónicos que aportan una identidad colectiva en base a una experiencia de la vida que a todos envuelve. Inspirados en buena medida por la imagen del carnaval, configuran una estética que transmite al mundo una imagen de belleza siempre explosiva y una felicidad al menos aparente, incluso en la mayoría de los casos químicamente inducida. La con- 
vocatoria de la música es el detonante de una necesidad más profunda de rebasar las propias fronteras. La tragedia debe vivirse como felicidad. Sísifo no tiene que suicidarse cuando se viste de Don Juan o de Dionisio. En ello está la felicidad.

En la misma línea podrían comprenderse determinadas manifestaciones de violencia y agresividad juvenil, tal como se manifiesta en grupos ultras de equipos de fútbol o en grupos xenófobos o racistas. La explosión violenta queda "justificada" ideológicamente. Pero no es más que una estrategia para ocultar la necesidad de mostrar la crueldad de la vida misma, la carencia de compasión que también forma parte del fluir de las energías vitales. En último término, también lo proclamaba Nietzsche, la existencia de los débiles no debe imponerse a la raza de los fuertes, de los aristócratas de la energía, de la fuerza, de la vida. El frenesí de lo inconsciente ha de buscar también estos derroteros de expresión. Y tampoco en este nivel hay culpa, pues existe una inocencia previa, la del ritmo de la vida.

El goce de la vida, en el sentido indicado, se expresa también, aún sin darse cuenta, en ambientes cristianos y eclesiales comprometidos. Desde esta clave se puede entender, a mi juicio, una reciente encuesta realizada por la CONFER entre jóvenes para conocer su actitud ante la vida religiosa o consagrada. Es importante observar que el campo de investigación está formado por jóvenes comprometidos desde su fe y vinculados personalmente a religiosos/as insertos en su realidad y en su mundo, lo que se considera "religiosos del futuro". Desde este presupuesto es comprensible la valoración altamente positiva de la vida consagrada. Se considera que son necesarios para la Iglesia y para la sociedad. Son reconocidos como testigos cualificados del Reino. Y sin embargo -y este es el punto que me interesa resaltar- son muy reticentes de cara a la posibilidad de optar ellos mismos por ese camino de vida cristiana. La razón es clara: vivir el seguimiento de Cristo bajo los consejos de pobreza, obediencia y castidad choca con otras apetencias profundamente humanas. La pobreza significa la renuncia a la capacidad de consumo y de posesión, la obediencia a la propia autonomía, la castidad al disfrute del cuerpo. Por ello resultan difícilmente aceptables, aunque se valore positivamente el modo de vida de quienes los han elegido, pero no por ellos mismos sino por otras aportaciones a la sociedad y a la Iglesia.

\section{7.- Evangelizar en una época trágica}

Indicábamos al principio la necesidad de conocer a los destinatarios del testimonio cristiano. Hemos intentado que esos destinatarios aparezcan ${ }_{n}$ ante 
nuestros ojos sobre el terreno en el que viven. Se nos ha impuesto la hondura y radicalidad de la savia de que se alimentan. Sus raíces brotan de una evolución cultural novedosa, de un auténtico cambio de civilización. Pero ello no nos debe conducir a una visión negativa o a una valoración peyorativa. El conocimiento ha de ser comprensión como solidaridad. No debe caer por ello en el rechazo de la condena o en la distancia de la indiferencia. Si se contempla a los hombres y mujeres contemporáneos con sensibilidad, con la sensibilidad de la fe, se les contemplará a la vez como protagonistas y como víctimas de un devenir histórico. Ser solidarios y hacerse prójimos brota de la experiencia de sentirse protagonistas del mismo drama. Aislarse sería otro modo de huida, sea por cobardía o por irresponsabilidad.

La situación sin embargo debe ser captada en su peculiaridad, y por ello en su novedad. En esto no se insistirá nunca lo suficiente. Tal vez sea arriesgado decir que se trata de la crisis más grave de la historia de la Iglesia. Pero igualmente sería, a nuestro juicio, inconsciente decir que es una más de las crisis de esa historia. Lo decisivo es comprender la peculiaridad que la hace nueva: está sucediendo algo original, único, sin que nos demos cuenta de modo lúcido y responsable. Sería interesante enumerar las estrategias utilizadas para evitar mirar de frente la novedad que viene irrumpiendo o las retóricas con que se elude el factor perturbador que se está generando. Baste sin embargo en este contexto insistir en la peculiaridad de un cambio de época, y en la configuración de un nuevo tipo de hombre, fenómenos a los que estamos asistiendo como espectadores pasivos.

Estas afirmaciones deben ser expresadas con claridad y contundencia, con toda su fuerza de interpelación, en un centro de estudios teológicos. En esta situación es cuando se impone la obligación de realizar su tarea con rigor intelectual y con responsabilidad ministerial. La teología no debe ser pensada ni vivida al margen del rumor de la calle y del clamor del tiempo. Y tampoco puede desconocer la inquietud que anida en muchos corazones creyentes. Precisamente por ello puede ser tarea apasionante y ministerio irrenunciable: cuando actúa en el seno de la vida de la Iglesia y de los acontecimientos históricos. La fascinación de la teología no puede experimentarse si se convierte en la rutina de una erudición que se repite. Resulta fascinante en cuanto se inserta en el protagonismo de la historia porque puede convertirse en aliento del propio modo de sentirse en la realidad, en la historia y en la Iglesia. Una catequesis o una pastoral que no estén impregnadas de esa fascinación se reducirá a profesionalización, a pedagogía o a estrategia.

La teología así comprendida, manteniendo su simpatía por sus contemporáneos pero conservando su obligación de ser vigía en la historia, ha de ejercer una función profética en la Iglesia, a fin de despertarla de su somno- 
lencia. Esa somnolencia provoca no sólo incapacidad para mirar la realidad de modo adecuado sino que, especialmente, bloquea la necesidad de recuperar el manantial de su ilusión evangelizadora. Si la Iglesia existe para evangelizar, hay que hacer ver a los miembros de la Iglesia que nos encontramos en el momento oportuno (es un kairós que debe ser aprovechado, ya que es interpelación a la Iglesia y ocasión de evento salvífico). Entonces la Iglesia estará en condiciones de recuperar su alegría genuina, porque sabrá lo que realmente puede aportar al mundo precisamente en esta época histórica. La queja y el lamento han de convertirse en doxología y en júbilo.

Esta actitud de la Iglesia debe asumirse desde la conciencia de participar en la encrucijada en la que se juega el destino del mundo, más concretamente del destino de Europa y de su cultura, de la conjugación del espíritu europeo con el cristianismo o con el paganismo. Creo que se puede afirmar que se trata de una situación análoga a la que se produjo en el primer encuentro entre la Iglesia naciente y el paganismo en decadencia. En la actualidad es el paganismo una fuerza emergente. La Iglesia deberá evitar que, desprovista de recursos o de atención, viva la experiencia de la decadencia.

Para ello la Iglesia debe convertirse de sus inercias y rutinas. La libertad que da lo originario sólo podrá brotar de la actualización de la experiencia fundante. Desde ella la fe cristiana puede aportar lo que es su tesoro más genuino y que resalta en todo su esplendor y peculiaridad precisamente en un contexto trágico: el appel y la interpelación personal, y por ello la experiencia de filiación, el sentido de la oración... y desde ahí la responsabilidad histórica, que va unida a la tarea evangelizadora.

Desde la relación de filiación (de sentirse interpelado con un nombre propio) se ha de mostrar en la historia el sentido de lo gratuito, como característica básica de lo personal, de la invocación y de la convocación. Lo gratuito debe mostrarse como tal en la cercanía a los desvalidos y necesitados. Sólo desde allí es posible el juicio de Dios. Porque ese juicio de Dios ha de resonar igualmente como juicio sobre el destino del mundo, sobre la marcha de la historia.

La experiencia gratuita de la filiación, que se regala desinteresadamente, hará que la Iglesia no se busque a sí misma, pues esa impresión es la que suscita más sospechas y reticencias. La Iglesia puede romper la lógica trágica como comunidad de la esperanza y de la alegría que se ofrece como alternativa de fraternidad, que mira a todos los hombres como hijos del Padre. Por ello la Iglesia, como experiencia de alegría compartida, se sitúa en medio de la historia como signo y sacramento, por ello como interpelación y posibilidad. La Iglesia ha de sentirse en misión desde la llamada que brota de una 
situación trágica. Sobre ese transfondo todo en ella será ejercicio del kerygma, del mensaje alegre de un Dios, el Dios pascual, que en la Iglesia interpela personalmente a los hombres.

La nueva y reciente experiencia de la Iglesia como Iglesia mundial, como comunión de iglesias que hablan todas las lenguas, ofrece posibilidades nuevas e insospechadas: la Iglesia está especialmente capacitada para ofrecer al mundo (en toda su amplitud) perspectivas nuevas y alternativas para las encrucijadas de una humanidad dividida todavía en sus intereses y conveniencias. La comunión eclesial de todos los bautizados debe vivirse y realizarse en y desde los problemas más acuciantes de la actual experiencia ecuménica y global.

Dada la transformación cultural y religiosa que hemos intentado describir y profundizar, la iniciación cristiana adquiere una nueva relevancia. No ha de realizarse meramente como transmisión de la fe, sino como exigencia del dinamismo del kerygma. Es en la iniciación cristiana donde está en juego la figura de la Iglesia del mañana que se está jugando en el presente. En ese punto de encuentro entre la Iglesia y el mundo que son los sacramentos de iniciación se debe discernir de un modo especial hasta dónde llega la fuerza de la religión para rescatar con mayor nitidez la debilidad de la fe, para que no caiga sometida bajo las necesidades religiosas de los hombres. Esa fe, que no puede más que ser personal, se impone en definitiva, aunque sea débil por ser personal, como la condición imprescindible de la evangelización que hoy se necesita.

Eloy BUENO DE LA FUENTE Facultad de Teología 